\title{
Egg quality and isoflavone deposition due to dietary inclusion of isoflavone soy sauce by-product (ISSBP) in laying hens
}

\author{
A. Malik ${ }^{1,2}$, E. Suprijatna ${ }^{3}$, V. D. Yunianto ${ }^{3}$, L. D. Mahfudz ${ }^{3, *}$ and N. Suthama ${ }^{3}$ \\ ${ }^{1}$ Graduate Program in Animal Science, Faculty of Animal and Agricultural Sciences, \\ Diponegoro University, Tembalang Campus, Semarang 50275 - Indonesia. \\ ${ }^{2}$ Permanent Address: Faculty of Agriculture and Animal Husbandry, \\ University of Muhammadiyah Malang, Karangploso, Malang 65152 - Indonesia \\ ${ }^{3}$ Faculty of Animal and Agricultural Sciences, Diponegoro University, \\ Tembalang Campus, Semarang 50275 - Indonesia. \\ .*CorrespondingE-mail: inditik@yahoo.com
}

Received March 24, 2018; Accepted April 23, 2019

\begin{abstract}
ABSTRAK
Penelitian bertujuan untuk mengkaji kualitas dan deposisi isoflavon dalam telur akibat penggunaan isoflavon ampas kecap dalam ransum ayam petelur. Ternak percobaan adalah 480 ayam petelur Isa Brown betina umur 20 minggu dengan bobot awal $1.754 \pm 42$ g. Penelitian disusun dalam rancangan acak lengkap (RAL) dengan 4 perlakuan dan 6 ulangan, terdapat 24 unit percobaan masing-masing berisi 20 ekor ayam. Perlakuan penggunaan level isoflavon ampas kecap (isoflavone soy sauce byproduct / ISSBP) dalam ransum sebagai berikut: ISSBP0 = tanpa isoflavon, ISSBP40 $=40 \mathrm{mg} / 100 \mathrm{~g}$, ISSBP $80=80 \mathrm{mg} / 100 \mathrm{~g}$, dan ISSBP120 $=120 \mathrm{mg} / 100 \mathrm{~g}$. Ransum perlakuan diberikan selama 10 minggu mulai umur 20 minggu sampai umur 30 minggu. Parameter yang diamati meliputi kolesterol telur, dan isomir isoflavon dalam ransum, darah dan telur. Data total kolesterol dan isoflavon telur dianalisis statistik dan isomer isoflavon pada pakan ransum, darah dan telur dievaluasi secara dekriptif. Hasil penelitian menunjukkan bahwa penggunaan isoflavon dari ampas kecap dalam ransum nyata $(\mathrm{P}<0,05)$ menurunkan kandungan kolesterol telur. Kolesterol total telur menurun $(\mathrm{P}<0,05)$ sampai $33,8 \%$, tetapi isoflavon dalam kuning telur $(28,9 \mathrm{mg} / \mathrm{g}$ protein) lebih tinggi $(\mathrm{P}<0,05)$ dari pada yang di dalam darah $(13,75 \mathrm{mg})$. Kualitas isoflavon dalam kuning telur lebih baik karena mengandung lebih banyak aglikons $(87,5 \%)$, dibandingkan dengan yang ada dalam ransum $(52 \%)$ dan darah $(68,4 \%)$. Kesimpulan, penggunaan isoflavon ampas kecap dalam ransum ayam petelur dapat menurunkan kolesterol dan meningkatkan kandungan isoflavon pada kuning telur dengan kualitas yang lebih baik, sehingga telur dapat berfungsi sebagai makanan fungsional.
\end{abstract}

Kata kunci: ampas kecap, ayam petelur, isoflavon, kolesterol, telur fungsional

\begin{abstract}
The objective of the study was to evaluate the quality and deposition of isoflavones in the egg due to dietary inclusion of isoflavone soy sauce by-product (ISSBP) in laying hens. Experimental animals were 480 birds of 20-week old laying hens of Isa Brown strain, with initial body weight of $1,754 \pm 42 \mathrm{~g}$. The experiment was arranged in a completely randomized design (CRD), with four treatments and six replications (20 birds each). The treatments were dietary inclusion levels of isoflavone soy sauce byproduct as follows: ISSBP0 $=$ without isoflavones, ISSBP40 $=40 \mathrm{mg} / 100 \mathrm{~g}$, ISSBP $80=80 \mathrm{mg} / 100 \mathrm{~g}$,
\end{abstract}


and ISSBP $120=120 \mathrm{mg} / 100 \mathrm{~g}$ feed. Dietary treatments were given for 10 weeks from week 20 until 30week old. Parameters observed were egg cholesterol and isoflavone isomers in feed, blood, and eggs. Data of total cholesterol and isoflavone in the egg were statistically analysed and isoflavone isomer concentration in feed, blood, and egg were descriptively described. The results showed that feeding ISSBP significantly $(\mathrm{P}<0.05)$ decreased cholesterol and increased isoflavones in egg. Total cholesterol content in egg decreased up to $33.8 \%$. However, isoflavones in the yolk were higher $(28.9 \mathrm{mg} / \mathrm{g})$ than those in blood $(13.75 \mathrm{mg} / \mathrm{g})$, and those deposited into the yolks indicated better quality because containing more aglicons isomers $(87.5 \%)$, than those in feed $(52 \%)$ and blood $(68.4 \%)$. In conclusion, dietary inclusion of ISSBP to laying hens's decreased cholesterol content and increased isoflavones deposition into the egg with better quality, so that the eggs can function as functional food.

Keywords: soy sauce by-product, laying hen, cholesterol, isoflavones, functional egg

\section{INTRODUCTION}

Poultry is known to have excellent bioconvertion properties, such as the ability to convert feed components into a good food, egg or meat, and is beneficial for human growth and health. Therefore, egg could be designed to improve the nutritional compounds to become a functional food that is beneficial for humans. Isoflavones in addition to functioning as antioxidants (Akdemir and Sahin, 2009; Yang et al., 2011; Ni et al., 2012) and phytoestrogens (Ni et al., 2012; Shi et al., 2013; Elkomy and Elghalid, 2014), they could also be used to improve the quality of poultry meat (Jiang et al., 2014), and egg production (Cai et al. 2013; Gu et al., 2013). Isoflavone could be transferred into the tissues of meat and eggs that is beneficial for human health (Markovic et al., 2015).

Research on feeding isoflavone from soy sauce by-product [ISSBP] to laying chicken in term of its deposition in egg and its quality has never been previously elucidated. This study is important for clarifying isoflavone soy sauce byproduct that has many advantages over other types of isoflavones as well as higher aglycone content. Soybean has glycoside content of $97.33 \%$, while aglycon was only $2.67 \%$, but after fermentation for 48 hours glycoside content decreased to $24.49 \%$ while aglycon increased to $75.51 \%$ (Silva et al., 2011). Increased isoplavone and active peptide aglycons have more health benefits (Hong et al., 2011).

The present study was conducted to evaluate feeding effect of ISSBP in laying chicken in relation to total cholesterol content and isoflavone deposition in yolk. The results of this study are expected to provide a new information concerning the development of poultry nutrition and feeding to produce the designed-egg rich in isoflavon antioxidant as functional food.

\section{MATERIALS AND METHODS}

\section{Experimental Animal and Diet}

Experimental animals were 20 -week old of 480 laying hens of Isa Brown strain with initial body weight of 1,754 $\pm 42 \mathrm{~g}$, and were placed randomly in battery cages. Feed was composed of corn gluten meal, distillery dried grain with soluble, fish meal, meat bone meal, yellow corn, rice bran, vegetable oil, oyster shell, methionine and soy sauce by-product. The composition and nutrients content of experimental feed is presnted in Table 1.

\section{Experimental Prosedures}

The present research was conducted by experimental method, using completely randomized design, with 4 treatments and 6 replications with 20 birds each. Inclusion levels of soy sauce by-product were created as dietary treatment as follows:

$\begin{array}{ll}\text { ISSBP0 } & : \begin{array}{l}\text { Control feed without isoflavon } \\ \text { soy sauce by-product (ISSBP) }\end{array} \\ \text { ISSBP40 } & : \begin{array}{l}\text { Feed contains ISSBP } 40 \mathrm{mg} / 100 \\ \text { g; or equal to5.8\% soy sauce by- } \\ \text { product }\end{array}\end{array}$

ISSBP80 : Feed contains ISSBP $80 \mathrm{mg} / 100$ $\mathrm{g}$; or equal to $11.6 \%$ soy sauce by-product

ISSBPP120 Feed contains ISSBP 120 $\mathrm{mg} / 100 \mathrm{~g}$; or equal to $17.4 \%$ soy sauce by-product

Parameters observed were cholesterol and the distribution of isoflavone isomers in feed, blood and eggs.

\section{Sampling Method and Analysis}

After the chickens were provided dietary treatment for 10 weeks, $2.5 \mathrm{~mL}$ blood sample was 
Table 1. Feed Ingredient Composition and Nutrition Content of Experimental Feed

\begin{tabular}{lrrrr}
\hline \multirow{2}{*}{ Ingredient } & \multicolumn{3}{c}{ Isoflavone Inclusion Level (mg/100g) } \\
\cline { 2 - 5 } & ISSBP0* & ISSBP40 & ISSBP80 & ISSBP120 \\
\hline Feed Composition (\%) & 46.00 & 44.80 & 45.60 & 45.60 \\
Yellow corn & 19.80 & 18.70 & 15.90 & 13.70 \\
Rice bran & 11.00 & 10.00 & 9.10 & 8.50 \\
Corn gluten meal & 9.00 & 7.10 & 5.00 & 2.00 \\
Distellers dried grain with solubles & 6.10 & 5.00 & 4.00 & 3.00 \\
Meat bone meal & 4.00 & 4.00 & 4.00 & 4.00 \\
Fish meal & 0.00 & 0.80 & 1.20 & 1.70 \\
Vegetable oil & 4.00 & 3.80 & 4.00 & 4.00 \\
Oyster shell & 0.07 & 0.06 & 0.05 & 0.04 \\
Methionine & 0.00 & 5.80 & 11.60 & 17.40 \\
Soy sauce by-product & 100.00 & 100.00 & 100.00 & 100.00 \\
Total & & & & \\
Nutrition Content** & 2.949 .72 & 2.949 .61 & 2.949 .66 & 2.949 .71 \\
Metabolizable energy (kcal/kg)*** & 17.93 & 17.96 & 18.01 & 18.03 \\
Protein (\%) & 6.32 & 6.75 & 6.76 & 6.86 \\
Ether extract (\%) & 3.19 & 3.15 & 3.01 & 2.91 \\
Crude fiber (\%) & 2.37 & 2.22 & 2.22 & 2.15 \\
Cacium (\%) & 0.75 & 0.71 & 0.66 & 0.60 \\
Phosphorus total (\%) & 0.66 & 0.66 & 0.67 & 0.67 \\
Lysine (\%) & 0.36 & 0.36 & 0.36 & 0.36 \\
Methionine (\%) & 0.00 & 40.00 & 80.00 & 120.00 \\
Isoflavone (mg/100g) & & & &
\end{tabular}

*ISSBP0 = feed without isoflavones

**Based on the laboratory analysis value of respective ingredients used for feed composition

*** Calculated based on the formula of Carpenter and Clegg (1965)

taken on day 70 from one bird in each replication. Blood was taken through the veins of the wings, and collected in EDTA-containing test tube for isoflavones analysis. Isoflavones in egg was determined in a mixture sampels of egg white and yolk. Quantitative analysis of isoflavones was performed using high performance liquid chromatography (HPLC) according to the modified procedure of Harborne (1992), and total cholesterol analysis based on the method of Kleiner and Dotti (1962). One egg was taken from each replication unit.

\section{Statistical Analysis}

Data of total cholesterol, and isoflavone isomer in the egg were statistically analysed by analysis of variance and were continued to least significant different (LSD) test (Steel and Torrie, 1991). Isoflavone isomer concentration in feed, blood, and egg were descriptively analyzed.

\section{RESULTS AND DISCUSSION}

\section{Isoflavones Profiles in Feed, Blood and Eggs}

Feeding isoflavones soy sauce by-product 
(ISSBP) indicated different effect on the isoflavones profiles in feed, blood, and eggs. Isoflavones analysis in feed, blood and eggs indicated varied content as presented in Table 2 . Results of the present study suggested that the transportation of isoflavones depending on the feed provided, and some interesting findings were found. First, in blood and egg samples of treatment without ISSBP inclusion $(0 \mathrm{mg})$ did not find isoflavones at all either in whole form or isomers (Table 2, and Figure 1). Control feed (ISSBP0) did not composed of ingredients derived from the type of beans in general or soybean meal in particular, as the source of isoflavones. Second, in the contrary, isoflavones content in eggs yolk dramatically revealed the increasing values when the birds were given dietary inclusion of ISSBP (ISSBP40 until ISSBP120), even the treatments of feeding ISSBP at $80 \mathrm{mg} / 100 \mathrm{~g}$ (ISSBP80) resulted significantly highest value both in whole form as well as in its isomers.

\section{Egg Cholesterol}

Total cholesterol in egg was significantly $(\mathrm{P}<0.05)$ decreased due to dietary inclusion of ISSBP. The highest cholesterol content of egg was found in group of laying hens provided control feed (Table 2 and Figure 2). When compared to control group (ISSBP0), feeding ISSBP40, ISSBP80, and ISSBP120 decreased egg cholesterol by $22.8,33.8$, and $29.9 \%$, respectively. This condition indicated that ISSBPP was

Table 2. Effect of Feeding ISSBPP on Cholesterol and Isoflavones of Egg Yolk

\begin{tabular}{lccrr}
\hline \multirow{2}{*}{ Variable } & \multicolumn{3}{c}{ Isoflavon Inclusion Level (mg/100g) } \\
\cline { 2 - 5 } & \multicolumn{1}{c}{ ISSBP0* } & \multicolumn{1}{c}{ ISSBP40 } & \multicolumn{1}{c}{ ISSBP80 } & \multicolumn{1}{c}{ ISSBP120 } \\
\hline Cholesterol (mg/g) & $12.70 \pm 0.4^{\mathrm{a}}$ & $9.80 \pm 0.3^{\mathrm{b}}$ & $8.40 \pm 0.2^{\mathrm{c}}$ & $8.90 \pm 0.2^{\mathrm{c}}$ \\
Isoflavone (mg/g) & nd & $28.80 \pm 0.9^{\mathrm{b}}$ & $33.40 \pm 1.1^{\mathrm{a}}$ & $24.50 \pm 0.8^{\mathrm{c}}$ \\
- Glycoside Isomers (\%) & nd & $12.37 \pm 0.4^{\mathrm{b}}$ & $14.35 \pm 0.5^{\mathrm{a}}$ & $10.18 \pm 0.3^{\mathrm{c}}$ \\
- Aglycone Isomers (\%) & nd & $87.03 \pm 1.8^{\mathrm{b}}$ & $85.65 \pm 1.7^{\mathrm{c}}$ & $89.82 \pm 1.9^{\mathrm{a}}$ \\
\hline
\end{tabular}

${ }^{\mathrm{a}-\mathrm{c}}$ Mean values with different superscripts within the same row differ significantly $(\mathrm{P}<0.05)$

$*=$ diet without isovlanes; nd $=$ not detected

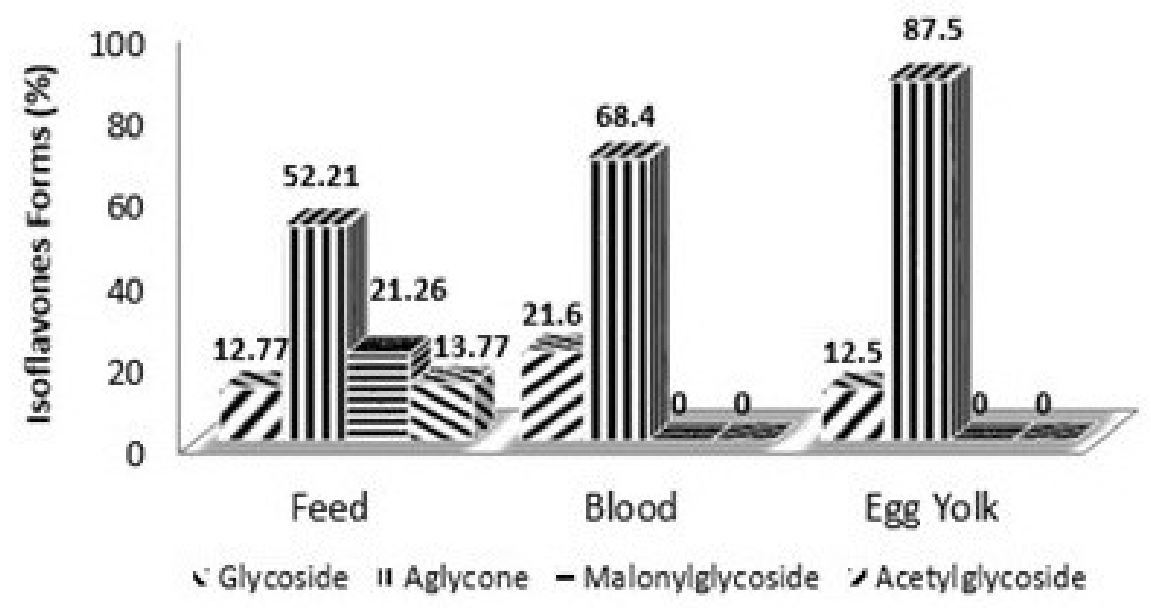

Figure 1. Isoflavone in Feed, Blood and Yolk. 


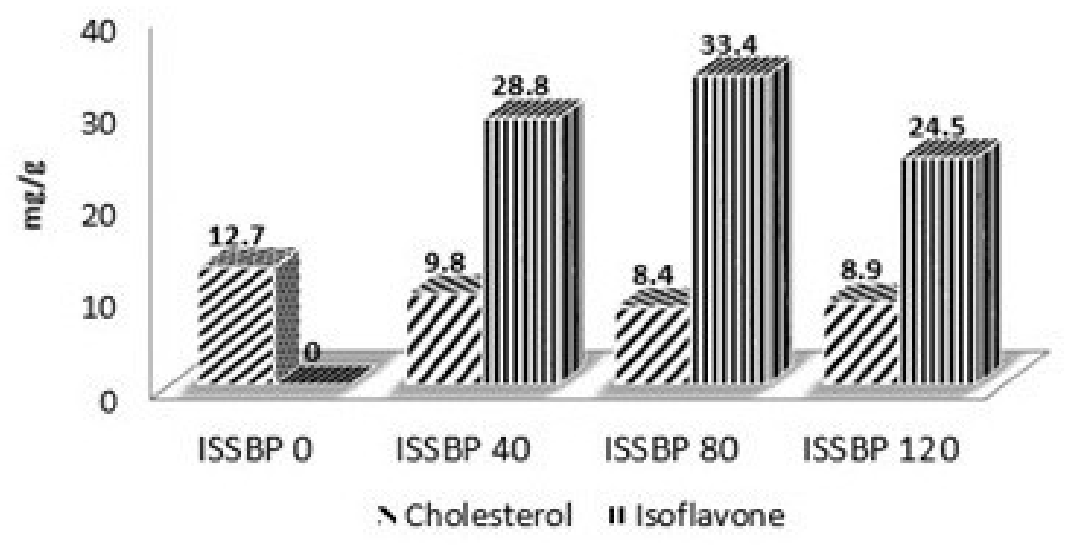

Figure 2. Cholesterol and Isoflavone in Yolk

effective in reducing egg cholesterol content of laying hens. The effectiveness of ISSBP in lowering the levels of egg cholesterol is closely related to the function of isoflavones as phytoestrogens. Isoflavones derived from soybean in general serve as phytoestrogens source which are known to have weak estrogenic hormone activity due to their structure is similar to $\beta$ estradiol. They can preferentially bind to estrogen receptor and mimicking the effects of estrogen in some tissues in one side, and blocking the effects of estrogen in other side. Due to its mode of action as eye scissors in which estrogenic effects in other tissues could help to maintain bone mineral density and improved egg production and shell quality (Markovic et al., 2015). On the other hand, because of their estrogenic blocking effects could improved blood lipid profiles and attributable to an impact on the decreased egg cholesterol found in the present study. Biochemical mechanism can be explained from the antagonistic activity of phytoestrogenes to depress endogenous estrogen produced by the developing follicle of the hens. This lead to the suppression of activity of HMG-CoA reductase enzyme which brought about the inhibition of cholesterol biosynthesis activity, consequently fewer endogenous cholesterol transported into the ovaries, but more were excreted through feces and urine (König et al., 2007; Vakili and Heravi, 2016).

\section{Isoflavone Deposition in Eggs}

Providing feed containing ISSBP significantly $(\mathrm{P}<0.05)$ increased yolk isoflavone content with the highest value was in ISSBP80 treatment, while hens fed control feed produced eggs without isoflavones. This phenomenon suggested that ISSBP in the feed can be transferred into the yolk depending on the level. This result was consistent with the report of Lin et al. (2004) who indicated that isoflavone genestein supplementation in quail feed increased the content of isoflavones in the yolk.The transportation mechanism of isoflavones into egg yolk have been clarified in connection with their changed into a conjugated form (Saitoh et al., 2004). Isoflavones were predicted to reduce by $30 \%$ during metabolism and approximately $70 \%$ were deposited into egg yolk in a conjugated form. Isoflavones changed to a conjugated form, a soluble isoflavones, causing it much easier to be transfered into egg yolk. Previous studies (Akdemir and Sahin, 2009; Lin et al., 2004) reported that isoflavone in egg yolk of quail increased due to dietary supplementation of soy isoflavones because the presence of genistein isomer form can be easier to be transferred into the yolk (Saitoh et al., 2004).This mechanism was likely seem to that of phytoestrogenes of ISSBP stimulated the liver to produce neutral fats and phospholipids to function as carrying substances. Therefore, conjugated form is absolutely possible to be constructed and carried by the blood into the ovaries for egg yolks formation.

The deposition rate of isoflavones in egg yolk which is mostly in the form of aglycone, was $87.6,85.7$, and $89.8 \%$ in ISSBP40, ISSBP80 and ISSBP120 treatments, respectively, and the remainder were isoflavones glycosides (Figure 3). 
A very high percentage of aglycone content in yolk when compared to isoflavones glycosides is assumed to be attributable to three factors. First, isoflavones in feed consisted of more aglycone around $54.21 \%$, while glycoside only $12.21 \%$, from total isoflavones content. Second, biotransformation process occured in the digestive tract brought about the change in glycoside into aglycone form. Third, isoflavones in the form of aglycone have higher absorptive rate than those in the form of glycosides. High aglycone concentration in egg yolk found in the present study is supported by the finding of Sanz and Luyten (2006) that the average absortive rate of aglycone (daidzein and genistein) was 83.5\% while that of glycosides (daizine and genestin) was only $60 \%$.

Isoflavones underwent a series of biotransformation process indicated by the difference in the number and composition of isoflavone isomers among feed, blood, and yolk (Figure 1). The presence of isoflavones in feed were in four forms, namely glycosides, aglycons, malonilglycosides, and acetylglycosides, whereas in the blood and egg yolk only isoflavone glycosides (genistin and daidzin) and aglycons (genetein and daidzain). The form of isoflavones in the blood was $68.36 \%$ the type of aglycons

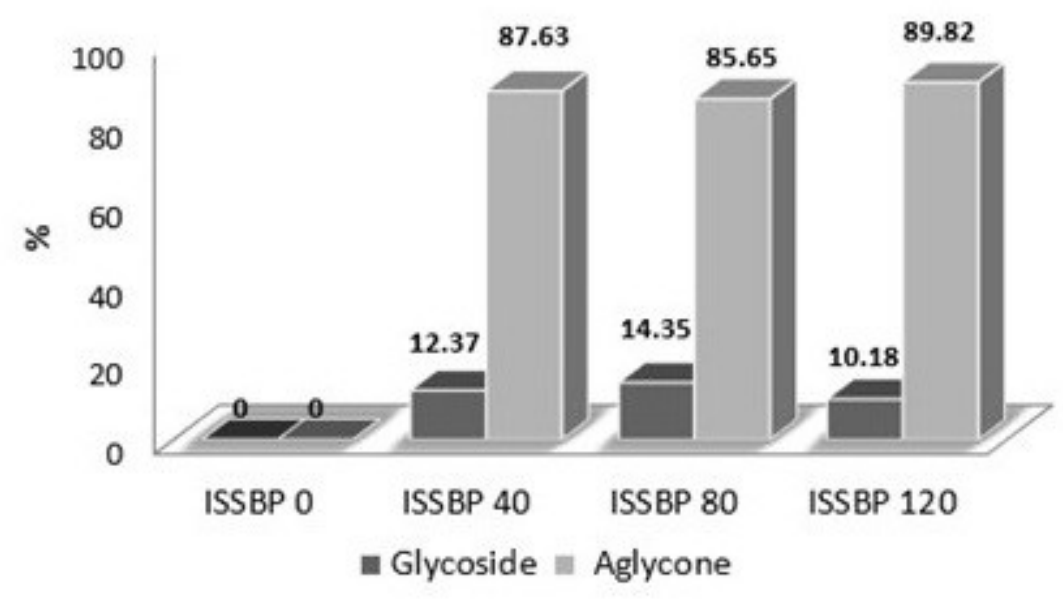

Figure 3. Isofalvones of Glycoside and Aglycone in Yolk

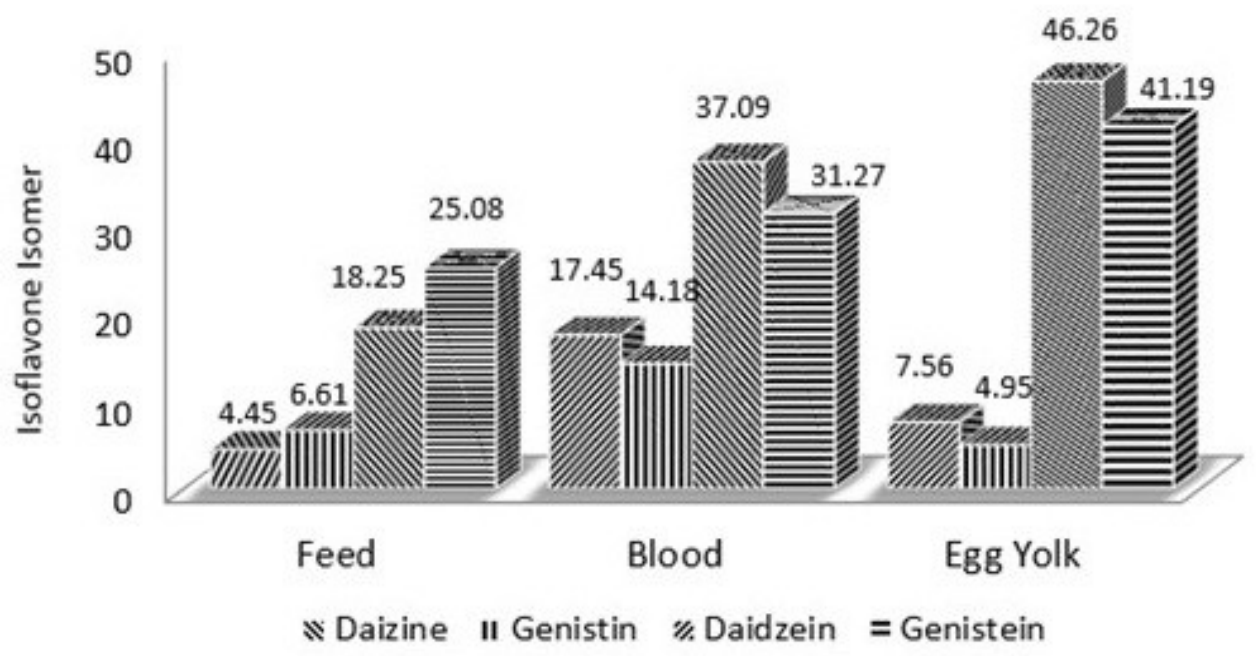

Figure 4. Isoflavone Isomer in Feed, Blood and Yolk 
(genistein $31.27 \%$ and daidzein $37.09 \%$ ) and that in egg yolk was equal to $87.45 \%$ (genistein $41.19 \%$ and daidzein $46.26 \%$ ), these concentrations were higher than that in feed was $49.52 \%$ (genistein $25.08 \%$ and daidzein $18.25 \%$ (Figure 4). While isoflavones in the digestive tract, they still underwent biotransformation process (Turner et al., 2004) that could change their form of malonilglycosides and acetylglycosides into glycosides and aglycons. This transformation occurs due to the fermentation process under the influence of $\beta$ glycosidase enzyme produced by intestinal microorganism. Similar phenomenon indicated that the glicitein isomer and its derivatives could be changed into other forms during the transformation process underwent in the chicken's body. Glicitin isomer and its derivatives were the most easily transformed group of isomers, during the processing of soybeans into soy sauce, and the change was also occured during transit time in the small intestine due to transformation.

\section{CONCLUSION}

Dietary inclusion of isoflavones soy sauce by-product (ISSBP) in laying hens, produce lower egg cholesterol content and rich in isoflavones dominated by aglycone, so that the eggs can function as functional food.

\section{REFERENCES}

Akdemir, F. And K. Sahin. 2009. Genistein supplementation to the quail: Effects on egg production and egg yolk genistein, daidzein, and lipid peroxidation levels. Poultry Sci. 88(10):2125-2131.

Cai, J., H. Gu, S. Shi and H. Tong, 2013. Effects of high-dose daidzein on laying performance, egg quality and antioxidation in laying hens. Poultry Sci. 50: 237-241.

Carpenter, K.J. and K.M. Clegg. 1965. The metabolizable energy of poultry feeding stuffs in relation to their chemical composition. J. Sci. Food Agric.7(1): 45-51.

Elkomy, A.E. and O.A. Elghalid. 2014. Physiological performance of broiler chicks fed on medicago sativa seeds as natural source of isoflavones. Asian J. Poult. Sci. 8(4): 97-105.

Gu, H., S.R. Shi, L.L. Chang, Z.Y. Wang, H.B.Tong and J.M. Zou. 2013. Safety evaluation of daidzein in laying hens: part
II. Effecs on calcium-related metabolism. Food Chem. Toxicol. 55:689-692.

Harborne, J.B. 1996. The Flavonoid : Advances in Research since 1986. London : Chapman \& Hall, Inc.

Hong, Y, G. Jin, D. Ren, S. Luo and T. Zhou. 2011. Mechanism of isoflavone aglycone's effect on cognitive performance of senescence-accelerated mice. Brain Cognit.76:206-2010.

Jiang, S.Q., J.Z. Jiang, G.L. Zhou, Y.C.Lin and C.T. Zheng. 2014. Effects of dietary isoflavone supplementation on meat quality and oxidative stability during storage in lingnan yellow broilers. J. Integr. Agric. 13(2):387-393.

Kleiner, I.S and I.B. Dotti. 1962. Laboratory Instruction in Biochemistry. Ed $6^{\text {th }}$ Mosby, New York.

König, B., H. Kluge, K. Haase, C. Brandsch, G. I. Stangl, and K. Eder. 2007. Effects of clofibrate treatment in laying hens. Poult. Sci. 86(6):1187-1195.

Lin, F.J. Wu, M. Abdelnabi, M. Ottinger, and M.M. Giusti. 2004. Effects of dose and glycosylation on the transfer of genestin into the eggs of Japanese quail (Coturnix japonica).J. Agric. Food Chem. 52(8): 2397-2403.

Markovic, R., M.Z. Baltic, M. Pavlovic, M. Glisic, S. Radulovic, V. Djordjevic, and D. Sefer. 2015. Isoflavones from biotechnology to functional foods. Procedia Food Sci. 5:176-179.

Ni, Y.D., J. Wu, H.Y. Tong, Y.B. Huang, L.Z. Lu, R.Gosmann and R.Q. Zhao. 2012. Effect of dietary daidzein supplementation on egg laying rate was associated with the change of hepatic VTG-II mRNA expression and higher antioxidant activities during the postpeak egg laying period of broiler breeders. Anim. Feed Sci. Technol. 177(1-2):116- 123

Saitoh, S., T. Sato, H. Harada and T. Matsuda. 2004. Biotransformation of soy isoflavone glycosides in laying hens: intestinal absorption and preferential accumulation into egg yolk of equol, a more estrogenic metabolite of daidzein. Biochim. Biophys. Acta. 1674(2):122-130.

Sanz, T. and H. Luyten. 2006. Release, partitioning and stability of isoflavones fromenriched custards during mouth, stomach and intestine in vitro simulations. Food Hydrocol. 206(6):892-900. 
Shi., S.R., H. Gu, L.L. Chang, Z.Y. Wang, H.B. Tong and J.M. Zou. 2013. Safety evaluation of daidzein in laying hens: part I. Effecs on laying performance, clinical blood parameters, and organs development. Food Chem. Toxicol. 55: 684-688.

Silva, L.H., R.M.S. Celeghini and Y.K. Chang. 2011. Effect the fermentation of whole soybean flour on the conversion of isoflavones from glycosides to aglycones. Food Chem. 128:640-644.

Steel, R.G.D and J.H. Torrie. 1991. Principles and Procedures of Statistics. 2nd Ed. International Book Company, Tokyo.

Turner, R., T. Baron, S. Wolffram, A.M.
Minihane, A. Cassidy, and G. Rimbach. 2004. Effect of circulating forms of soy isoflavones on the oxidation of low density lipoprotein. Free Radic. Res. 38(2):209216.

Vakili, A. and M. Heravi. 2016. Performance and Egg Quality of Laying Hens Fed Diets Supplemented with Herbal Extracts and Flaxseed. Poult. Sci. 4(2):107-116.

Yang, H., G. Jin, D. Ren, S. Luo and T. Zhou. 2011. Mechanism of isoflavone aglycones effect on cognitive performance of senescence-accelerate mice. Brain Cognit. 76(1):206-210. 